\title{
EFFECT OF CERTAIN CHEMICAL PRESERVATIVE SOLUTIONS ON VASE LIFE AND POSTHARVEST CHARACTERISTICS OF CARNATION Dianthus caryophyllus cv. Felice CUT FLOWERS
}

(Received: 25.8. 2014)

\author{
By \\ M. A. Darwish, F.E. M. El-Quesni" and E. A. El-Shereef* \\ Ornamental Horticulture Department, Faculty of Agriculture, Cairo University, Giza, Egypt. \\ *Ornamental Plants and Woody Trees Department, National Research Center, Dokki, Giza, Egypt.
}

\begin{abstract}
This experiment was carried out in the laboratory of Ornamental Plants and Woody Trees Department at the National Research Center, Dokki, Giza, Egypt, during two successive seasons (2008 and 2009) to investigate the effect of some chemical preservative solutions such as 8hydroxyquinoline sulphate (8-HQS) alone or with sucrose or benzyl adenine (BA), or gibberellic acid $\left(\mathrm{GA}_{3}\right)$ ), citric acid, alone or with sucrose and silver thiosulphate (STS) alone or with sucrose. Also, aluminum sulphate $\left[\mathrm{Al}_{2}\left(\mathrm{SO}_{4}\right)_{3}\right]$ alone or with $\mathrm{BA}$ or $\mathrm{GA}_{3}$, in addition to the control (distilled water) on vase life. and maximum increase in fresh weight i.e as keeping quality and change in fresh weight and water balance of carnation Dianthus caryophyllus cv."Felice" cut flowers.Using solution of (300 ppm 8 -HQS $+40 \mathrm{~g} / \mathrm{l}$ sucrose) and $(0.4 \mathrm{mM}$ STS $+50 \mathrm{~g} / \mathrm{l}$ sucrose) significantly increased vase life and maximum increase in fresh weight compared with control (distilled water). Pulsing carnation cut flowers in $50 \mathrm{ppm} \mathrm{GA}$ for $24 \mathrm{~h}$. then placed in $200 \mathrm{ppm} \mathrm{Al}_{2}\left(\mathrm{SO}_{4}\right)_{3}$ showed the highest values of increase in fresh weight $\%$ after 12 days in the $2^{\text {nd }}$ season $(12.63 \%)$. The highest level of water balance was recorded at $12^{\text {th }}$ days by using $50 \mathrm{ppm}$ of $\mathrm{GA}_{3}$ for $24 \mathrm{~h}$. then placed in $\mathrm{Al}_{2}\left(\mathrm{SO}_{4}\right)_{3}$ in the $2^{\text {nd }}$ season.
\end{abstract}

Key words: Dianthus caryophyllus, keeping quality, 8-HQS, STS, $\mathrm{Al}_{2}\left(\mathrm{SO}_{4}\right)_{3}$, sucrose, vase life.

\section{INTRODUCTION}

About $20 \%$ of fresh flowers lose their quality while passing through the market (harvest, packing, transportation and sale) and a large percentage of the remaining flowers are sold at low quality conditions dissatisfying the consumer (Asfarani et al., 2008) due to physiological problems during the post-harvest handling. Under normal conditions, cut flowers last only for a few days maintaining their beauty and attractiveness. However, most of the people like to enjoy them in their natural beauty and appearances for a longer period of time (Zamani et al., 2011). Thus, using appropriate preservatives could help to extend the vase life of the harvested produce for consumer satisfaction and exploitation of the business.

Dianthus caryophyllus L. (carnation) fam. Caryophyllaceae is one of the most important cut flower nowadays. Therefore, it is important to ensure the longest vase life of the flowers. Various factors influence the postharvest performance and the vase life of cut flowers (Mayak et al., 1974 and Ichimura et al., 2002).
Vase life is influenced by genetics, the growing conditions, flower handling (Pizano, 2009), carbohydrate content, block-age of xylem vessels, ethylene, the composition of the atmosphere, and the chemical solutions of the preservatives. After harvest, the longevity of flowers is limited by rapid petal wilting. Floral preservatives have been found to delay the senescence by suppressing the microbial growth and promoting solution uptake due to reduction in vascular blockage (Asrar, 2012 and Elhindi, 2012). Silver thiosulphate (STS) allow for a better adjustment of flower supply to the requirements of the market and to a greater extent eliminates the postharvest losses. Some chemical preservatives increased vase life of cut flowers, i.e. citric acid with sucrose $2 \%$ (Patil and Reddy 2005) on Solidago canadensis, or aluminum sulphate as biocide alone or with sucrose were used to prolong vase life (Chen et al., 2004) on Gerbera hybrida and (Mohamed et $a l ., 2012)$ on roses, and increased fresh weight. The influence of mineral salts such as $\mathrm{Al}_{2}\left(\mathrm{SO}_{4}\right)_{3}$ on the physiological and biochemical changes of 
cut rose (Rosa hybrida) in addition to the extension of vase life, was attributed to their effects in increasing the permeability of cell membrane and keeping the peroxidative changes at a minimum rate (Bhaskar et al., 2003). Sucrose was the kind of sugar mostly used in floral preservatives; the increase of vase life due to sucrose may result from a decreased moisture stress and improved water balance (El Zohairy 1999) on some cut flowers. Gue et al. (2004) stated that $\mathrm{BA}$ and $\mathrm{GA}_{3}$ both prolonged vase life, while BA inhibited ethylene production, and that $\mathrm{BA}$ is the main factor regarding senescence of cut chrysanthemum. Using the floral preservative solution 8-hydroxy quinolone sulphate (8-HQS) as ethylene antagonist, Elgimabi and Sliai, (2013) reported that 200 ppm 8-HQS combined with 7\% sucrose increased vase life of Rosa domascena cv. Trigintipetala and retarded the chlorophyll as well as carbohydrate degradation.

\section{MATERIALS AND METHODS}

The present study was conducted at the laboratory of Ornamental Plants and Woody Trees Department, National Research Center during two successive seasons (2008 and 2009). The aim of this study was to investigate the effect of using some chemical preservative solutions on the vase life of carnation cut flowers (Dianthus caryophyllus) cv. Felice. The cut flowers were obtained directly from a commercial growing farm "Floramix Farm". The flowers were cut early in the morning kept in ice box collar (precooled) and transported to the laboratory within one hour. The leaves from the third lower part of the stem and five $\mathrm{cm}$ from the base of the stem were removed under running water to prevent air bubbles getting into the cut end, then placed in cold water for $15 \mathrm{~min}$ The all stems were tremmed to uniform length of 50 $\mathrm{cm}$ for carnation cut flowers. The details of the treatments of chemical solutions used were as follows:

1. Distilled water, as control.

2. $300 \mathrm{ppm} 8$-HQS.

3. $300 \mathrm{ppm} 8-\mathrm{HQS}+40 \mathrm{gm} / 1$ sucrose.

4. $150 \mathrm{ppm} 8-\mathrm{HQS}$.

5. $150 \mathrm{ppm} 8$-HQS $+20 \mathrm{gm} / 1$ sucrose.

6. $0.4 \mathrm{mM}$ STS for $6 \mathrm{~h}$.

7. $0.4 \mathrm{mM}$ STS for $6 \mathrm{~h} .+50 \mathrm{gm} / 1$ sucrose.

$8.150 \mathrm{ppm}$ citric acid.

9. $150 \mathrm{ppm}$ citric acid $+20 \mathrm{gm} / 1$ sucrose.

10. $200 \mathrm{ppm}$ Aluminum sulphate
11. $50 \mathrm{ppm} \mathrm{GA}_{3}$ for $24 \mathrm{~h}$. then placed in $200 \mathrm{ppm}$ $\mathrm{Al}_{2}\left(\mathrm{SO}_{4}\right)_{3}$

12. $50 \mathrm{ppm} \mathrm{BA}$ for $24 \mathrm{~h}$. then placed in $200 \mathrm{ppm}$ $\mathrm{Al}_{2}\left(\mathrm{SO}_{4}\right)_{3}$

13. $50 \mathrm{ppm} \mathrm{GA}$ for $24 \mathrm{~h}$.then placed in $200 \mathrm{ppm}$ 8 -HQS.

14. $50 \mathrm{ppm}$ BA for $24 \mathrm{~h}$. then placed in $200 \mathrm{ppm}$ 8 -HQS.

The recorded data were:

* Vase life (days).

* Maximum increase in fresh weight $\%$ :

Fresh weights of carnation cut flowers were measured daily during vase life. The original fresh weight was measured immediately after cutting flowers and before the immersing in keeping solutions. The flowers were weighted every 2 days until the end of the vase life. The fresh weight of each cut flower was expressed relative to their initial weights to represent the percentage of weight loss for each cut flower stem (He et al., 2006).

* Change in fresh weight\% was recorded just before the beginning of the treatment then every two days, i.e. 2, 4, 6, 8, 10 and 12 days.

* Water balance: During shelf life period The rate of water balance $=$ the rate of water uptake - the rate of water loss.

* Water uptake: The weight of absorbed preservative solutions (g) was recorded every two days i.e." $2,4,6,8,10$ and12 days."

* Water loss: (g/flower) was measured as a difference between the weight of the jars with the flowers, every two days $(2,4,6,8$, 10 and 12days) and the weight of the jars with flowers at the beginning of the experiment.

\section{RESULTS AND DISCUSSION \\ 3.1. Effect of different vase solutions on vase life (days ) of carnation flowers}

The data recorded in Table (1) indicated showed that all the tested vase solutions significantly prolonged the longevity on vase life (days) of carnation cut flowers as compared with the control (distilled water), in both seasons. The best treatment was $300 \mathrm{ppm} 8$-HQS + $40 \mathrm{~g} / \mathrm{l}$ sucrose, which gave 12.90 and 13.03 days in $1^{\text {st }}$ and $2^{\text {nd }}$ seasons compared to 7.87 and 7.07 days for the untreated control, respectively. STS treatment improved the vase life of carnation cut flowers. The longest vase life was obtained by the treatment of $0.4 \mathrm{mM}$ STS for 6 hours +50 $\mathrm{g} / \mathrm{l}$ sucrose, with a significant increase which 
gave 13.33 and 13.0 days in the $1^{s t}$ and the $2^{\text {nd }}$ seasons, respectively, compared with the untreated control (distilled water).

Pulsing carnation cut flowers in $50 \mathrm{ppm} \mathrm{GA}$ for $24 \mathrm{~h}$., then placed in $200 \mathrm{ppm} \mathrm{Al}_{2}\left(\mathrm{SO}_{4}\right)_{3}$ and $50 \mathrm{ppm}$ BA for $24 \mathrm{~h}$., then placed in $200 \mathrm{ppm} 8$ HQS significantly increased vase life which recorded ( 12.50 and 14.00 days) and (11.07 and 12.00 days) in the $1^{\text {st }}$ and the $2^{\text {nd }}$ seasons, respectively.

Pulsing carnation cut flowers in $50 \mathrm{ppm}$ gibberellic acid $+200 \mathrm{ppm} \mathrm{Al}_{2}\left(\mathrm{SO}_{4}\right)_{3}$ or $50 \mathrm{ppm}$ BA for $24 \mathrm{~h}+200 \mathrm{ppm}$ 8-HQS treatments slightly enhanced flower longevity in carnation cut flowers. These results agreed with those obtained by Gue et al. (2004) on P. tuberosa, who found that BA and GA3 both prolonged vase life and delayed premature wilting, in addition to BA inhibiting ethylene production. $\mathrm{BA}$ is the main factor retarding the senescence of cut chrysanthemum flowers, (Patil and Reddy, 2005) on Solidago canadensis and Skutnik et al. (2006) on asparagus.

The active role of 8-HQS could be explained also by maintaining flower turgidity, by keeping fresh weight and chlorophyll as well as carbohydrates losses by 8 -HQS to a minimum. These results are in agreement with the findings of Knee (2000) on rose, Kim and Lee (2002) and Samaneh et al., (2013) on gerbera flowers.

The results indicate the importance of 8-HQS in increasing the vase life of cut flowers, where 8-HQS prevented the accumulation of microorganisms in xylem vessels and suppressed xylem occlusion. These results may be due to the role of $8-\mathrm{HQS}$ as antimicrobial agent and it might be reducing stem plugging and increasing vase life, (El-gimabi and Sliai 2013).

The effective role of STS in prolonging vase life of cut flowers may be due to the percentage of weight loss, and chlorophyll degradation minimized, and as consequence the vase life was extended. These results are in harmony with the results of Asrar (2012) on Antirrhinum majus L. and Elhinidi (2012) on sweet pea cut flowers and Samaneh et al. (2013) on gerbera cut flowers.

\subsection{Maximum increase of fresh weight $\%$}

From the data in Table (1), it is obvious that these treatments significantly increased the maximum increase of fresh weight $\%$ in most treated carnation cut flowers with preservative solutions in both seasons than distilled water, as control.

It should be mentioned that the highest values of significant increases of fresh weight were (18.31 and $19.76 \%$ ) when 300 ppm 8-HQS +40 $\mathrm{g} / \mathrm{l}$ sucrose was used on carnation cut flowers in the first and second seasons, respectively. However the lowest values of this parameter were (9.77 and 9.04\%) when carnation cut flowers were held in preservative solution containing $200 \mathrm{ppm}$ aluminum sulphate in both

Table (1):Effect of the preservative solution treatments on vase life (days) and maximum increase of fresh weight \% of Dianthus caryophyllus cv. "Felice"cut flowers in 2008 and 2009 seasons.

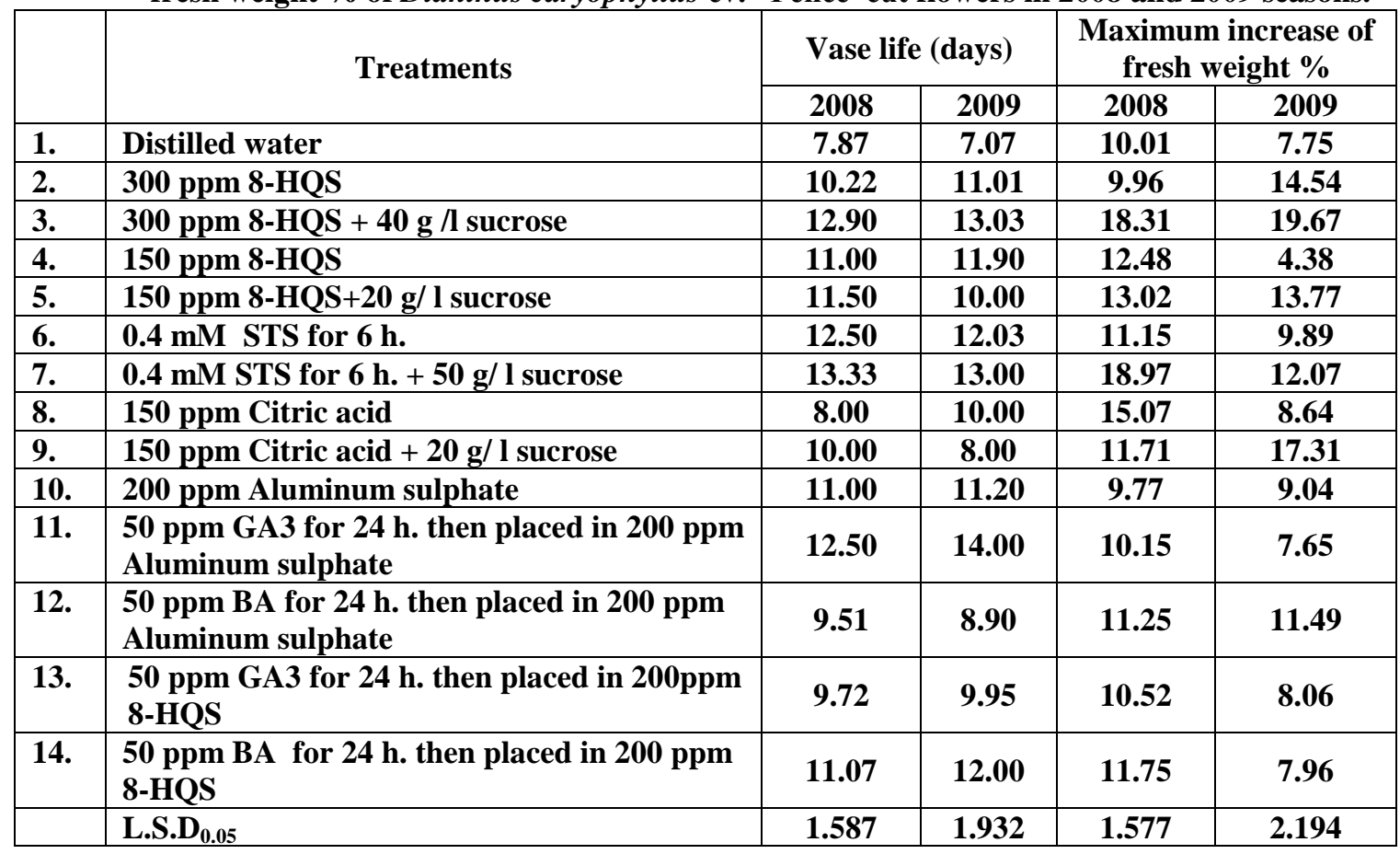


seasons, respectively. These results coincided with the results obtained by Taha and Soad (2010) on sterlitzia, who mentioned that preservative vase solutions recorded higher daily increase of fresh weight percentage, where, the flower weight, expressed the flower freshness, flower longevity and senescence. Steinitz (1982) pointed out that addition of sucrose to the solution increased the mechanical turgidity of stem by inducing cell wall thickening and lignification of vascular tissues. Sucrose or its combination with biocides is a main limiting factor in postharvest life of cut flowers (Kazemi et al., 2011) and improved postharvest performance on tuberose (Gul and Tahir 2013).

3.3.The change of fresh weight $\%$ of carnation cut flowers during shelf life period

From the recorded data in Tables (2 and 3), it can be concluded that the change of fresh weight $(\%)$ of carnation cut flowers gained an increase gradually by increasing the number of days during the shelf life period, and this increase differ according to the treatments of preservative solutions. The data revealed that the fresh weight gain decrease in $300 \mathrm{ppm}$ 8-HQS (2.53 from $1.59 \%$ ), and the highest value was found after 6 days after that. The increase in fresh weight started to decrease in the $1^{\text {st }}$ season, while in the $2^{\text {nd }}$ season $300 \mathrm{ppm} 8$-HQS $+40 \mathrm{~g} / 1$ sucrose treatment gain significant increased to $6.61 \%$. This was found after 8 days compared to the control $(-4.03 \%)$ and after that, the increase in fresh weight started to decrease.
The same observation was also noticed in 0.4 mM STS for $6 \mathrm{~h} .+50 \mathrm{~g} / 1$ sucrose which resulted in a significant increase in fresh weight from 2.53 to $10.87 \%$ after 6 days during shelf life period in the $1^{\text {st }}$ season, and in the $2^{\text {nd }}$ season the same treatment gained increase in fresh weight from 7.65 to $9.90 \%$ compared with distilled water $(7.65 \%)$ after 6 days during shelf life period, then gained significant increase in fresh weight from (-8.07 to $16.20 \%)$ after 12 days during shelf life period, then decreased after that until the end of the shelf life period. However, $50 \mathrm{ppm}$ GA3 for $24 \mathrm{~h}$. then placed in $200 \mathrm{ppm}$ $\mathrm{Al}_{2}\left(\mathrm{SO}_{4}\right)_{3}$ exhibited the highest values of increase in fresh weight $\%$ after 12 days in the $2^{\text {nd }}$ season $(12.63 \%)$. These results are in agreement with those obtained by Patil and Reddy (2001) and Patil et al. (2003) on solidago, they mentioned that flower stalks in sucrose solutions with 8-HQS maintained higher rates of fresh weight in solidago, morosely Mohamed et al. (2012) mentioned that $\mathrm{Al}_{2}\left(\mathrm{SO}_{4}\right)_{3}$ increased vase life and fresh weight. It seems that antimicrobial effect of the applied beneficial treatments led to the declined vascular blockage, higher solution uptake and fresh weight in treated cut flowers, by which the senescence process was delayed (Kazemi et al., 2011).

3.4.Effect of the different vase solution treatments on water balance of carnation cut flowers

Data presented in Tables (4 and 5) showed that treated flowers with different preservative

Table (2): Effect of different vase solutions on the change in fresh weight $\%$ of carnation, Dianthus caryophyllus cv."Felice" cut flowers, in the first season (2008).

\begin{tabular}{|c|c|c|c|c|c|c|c|}
\hline \multirow{2}{*}{\multicolumn{2}{|c|}{ Vase solutions }} & \multicolumn{6}{|c|}{ Days after treatments } \\
\hline & & 2 & 4 & 6 & 8 & 10 & 12 \\
\hline 1 & Distilled water & 3.87 & 3.06 & 2.53 & -8.44 & -6.63 & -5.99 \\
\hline 2 & 300 ppm 8-HQS & 6.48 & 1.17 & 1.59 & -2.86 & -3.62 & -3.75 \\
\hline 3 & 300 ppm 8-HQS + 40 g sucrose & 5.49 & 4.05 & 4.35 & 2.60 & -2.94 & -1.46 \\
\hline 4 & 150 ppm 8-HQS & 3.99 & 3.36 & 4.17 & -3.32 & -11.33 & -10.11 \\
\hline 5 & 150 ppm 8-HQS+20 g sucrose & 3.39 & 2.04 & 6.51 & -6.07 & -6.60 & -10.77 \\
\hline 6 & $0.4 \mathrm{~m} \mu$ STS for $6 \mathrm{~h}$. & 1.78 & 4.80 & 2.89 & 0.95 & -7.47 & -7.26 \\
\hline 7 & $0.4 \mathrm{~m} \mu$ STS for $6 h_{.}+50 \mathrm{~g}$ sucrose & 3.08 & 2.68 & 10.87 & 4.54 & 5.13 & -1.11 \\
\hline 8 & 150ppm Citric acid & 5.49 & 3.17 & 3.45 & 1.66 & -3.12 & -1.38 \\
\hline 9 & 150ppm Citric acid + 20 g sucrose & 3.97 & 6.34 & 5.96 & 2.46 & 1.44 & -1.31 \\
\hline 10 & 200ppm Aluminum sulphate & 2.70 & 3.75 & 2.75 & -0.74 & -11.78 & -16.55 \\
\hline 11 & $\begin{array}{l}50 \mathrm{ppm} \text { GA3 for } 24 \mathrm{~h} \text {. then placed in } 200 \\
\text { ppm Aluminum sulphate }\end{array}$ & 2.78 & 1.75 & 3.44 & 1.56 & -1.14 & -1.61 \\
\hline 12 & $\begin{array}{l}50 \mathrm{ppm} \text { BA for } 24 \mathrm{~h} \text {. then placed in } 200 \\
\text { ppm Aluminum sulphate }\end{array}$ & 3.31 & 3.87 & 3.31 & -2.53 & -13.89 & -13.75 \\
\hline 13 & $\begin{array}{l}50 \text { ppm GA3 for } 24 \mathrm{~h} \text {. then placed in } 200 \\
\text { ppm 8-HQS }\end{array}$ & 1.93 & 1.67 & 2.41 & -1.06 & -4.67 & -5.41 \\
\hline 14 & $\begin{array}{l}50 \text { ppm BA for } 24 \mathrm{~h} \text {. then placed in } 200 \\
\text { ppm 8-HQS }\end{array}$ & 2.95 & 4.29 & 3.71 & -1.35 & -8.79 & -13.28 \\
\hline
\end{tabular}


Table (3): Effect of different vase solutions on the change in fresh weight $\%$ of carnation Dianthus caryophyllus, cv."Felice" cut flowers, in the second season (2009).

\begin{tabular}{|c|c|c|c|c|c|c|c|}
\hline \multirow{2}{*}{\multicolumn{2}{|c|}{ Vase solutions }} & \multicolumn{6}{|c|}{ Days after treatments } \\
\hline & & \multirow{2}{*}{$\begin{array}{c}2 \\
-2.39\end{array}$} & \multirow{2}{*}{$\begin{array}{c}4 \\
1.74\end{array}$} & \multirow{2}{*}{$\begin{array}{c}6 \\
7.65 \\
\end{array}$} & \multirow{2}{*}{$\begin{array}{c}8 \\
-4.03 \\
\end{array}$} & \multirow{2}{*}{$\begin{array}{c}10 \\
-6.99 \\
\end{array}$} & \multirow{2}{*}{$\begin{array}{c}12 \\
-8.06 \\
\end{array}$} \\
\hline 1. & Distilled water & & & & & & \\
\hline 2. & 300 ppm 8-HQS & 1.65 & 0.18 & 2.03 & -1.92 & -2.88 & -2.52 \\
\hline 3. & 300 ppm 8-HQS + $40 \mathrm{~g} / 1$ sucrose & 2.34 & -11.37 & 4.43 & 6.61 & -11.99 & -1.23 \\
\hline 4. & $150 \mathrm{~m}$ 8-HQS & 4.93 & -0.55 & -0.41 & -14.09 & -1.98 & -8.57 \\
\hline 5. & 150 ppm 8-HQS+20 g/ 1 sucrose & -0.24 & 6.22 & -0.15 & 6.47 & -11.78 & -10.43 \\
\hline 6. & $0.4 \mathrm{~m} \mu \mathrm{STS}$ for $6 \mathrm{~h}$. & -19.31 & 23.25 & 0.06 & -0.90 & -4.02 & -1.96 \\
\hline 7. & $0.4 \mathrm{~m} \mu$ STS for $6 \mathrm{~h} .+50 \mathrm{~g} / 1$ sucrose & -4.00 & 13.91 & 9.90 & -13.23 & 0.39 & 16.20 \\
\hline 8. & 150 ppm Citric acid & 12.77 & -8.35 & 2.07 & 18.17 & -21.73 & -5.56 \\
\hline 9. & $150 \mathrm{ppm}$ Citric acid $+20 \mathrm{~g} / 1$ sucrose & 8.42 & 0.62 & 7.00 & -0.79 & -3.82 & -0.29 \\
\hline 10. & $200 \mathrm{ppm}$ Aluminum sulphate & 6.27 & -2.56 & 4.32 & -2.49 & -12.29 & -10.97 \\
\hline 11. & $\begin{array}{l}50 \mathrm{ppm} \text { GA3 for } 24 \mathrm{~h} \text {. then placed in } \\
200 \mathrm{ppm} \text { Aluminum sulphate }\end{array}$ & -1.83 & -2.09 & 10.21 & 0.40 & -29.53 & 12.63 \\
\hline 12. & $\begin{array}{l}50 \mathrm{ppm} \text { BA for } 24 \mathrm{~h} \text {. then placed in } \\
200 \mathrm{ppm} \text { Aluminum sulphate }\end{array}$ & 2.31 & 4.20 & 0.30 & 3.71 & -9.69 & -11.81 \\
\hline 13. & $\begin{array}{l}50 \mathrm{ppm} \text { GA3 for } 24 \mathrm{~h} \text {. then placed in } \\
200 \mathrm{ppm} 8 \text {-HQS }\end{array}$ & 0.95 & -0.91 & -2.35 & 4.23 & -7.66 & -10.01 \\
\hline 14. & $\begin{array}{l}50 \mathrm{ppm} \text { BA for } 24 \mathrm{~h} \text {. then placed in } \\
200 \mathrm{ppm} 8-\mathrm{HQS}\end{array}$ & 3.00 & 0.36 & 1.32 & 2.86 & -17.01 & -15.16 \\
\hline
\end{tabular}

solutions recorded the highest level of water balance by 300ppm 8-HQS + $40 \mathrm{~g} / \mathrm{l}$ sucrose which gave $(0.71 \mathrm{~g} /$ flower $)$ on the $10^{\text {th }}$ day in the $1^{\text {st }}$ season, $0.4 \mathrm{mM}$ STS for $6 \mathrm{~h} .+50 \mathrm{~g} / \mathrm{l}$ sucrose gave $(1.56 \mathrm{~g} /$ flower $)$ on the $10^{\text {th }}$ day and 150 ppm citric acid $+20 \mathrm{~g} / \mathrm{l}$ sucrose gave $(0.69$ g/flower) on the $8^{\text {th }}$ day in the $1^{\text {st }}$ season compared to other treatments and the control cut flowers. However, in the second season, the highest level of water balance was (8.61 g/flower) at the $12^{\text {th }}$ day by using $50 \mathrm{ppm}$ GA3 for $24 \mathrm{~h}$. then placed in $200 \mathrm{ppm} \mathrm{AL}\left(\mathrm{SO}_{4}\right)_{3}$. Using $0.4 \mathrm{mM}$ STS for $6 \mathrm{~h} .+50 \mathrm{~g} / 1$ sucrose up to the $10^{\text {th }}$ day gave (1.31 and $3.98 \mathrm{~g} /$ flower) in the $1^{\text {st }}$ and the $2^{\text {nd }}$ seasons, respectively. While, $150 \mathrm{ppm}$ citric acid $+20 \mathrm{~g} / \mathrm{l}$ sucrose at the $6^{\text {th }}$ day gave (1.63 and $1.81 \mathrm{~g} / \mathrm{flower})$ in the $1^{\text {st }}$ and the $2^{\text {nd }}$ seasons, respectively, and $300 \mathrm{ppm} 8$-HQS + $40 \mathrm{~g} / 1$ sucrose up to the $8^{\text {th }}$ day gave $(1.71$ g/flower) in the $2^{\text {nd }}$ season compared to other treatments. Cut flowers turgidity is the result of the balance between the level of water uptake and water loss. Sugars improve the water balance in cut flowers and this was attributed to the effect of sucrose on the closure of stomata and reduction of water loss, (Halevy and Mayak,
1981). The sugars accumulate in the flowers, increasing their osmotic concentration and improving their ability to absorb water and maintain their turgidity. Gul and Tahir (2013) found that STS increased solution uptake on Narcissus pseudonarcissus which increased water balance. This is due to the carbohydrates being the main source of nutrition and energy necessary for maintaining all biochemical and physiological process after separation from the mother plant. This beneficial effect is attributed to the improvement of water relation and increase in respiration adding 8 -HQS to the preservative vase solution, acts also as bactericide and reduces $\mathrm{pH}$ of solution, which improved the solution absorption. El-Zohairy (1999) reported that 8-HQS treatments increased water balance of Rosa hybrida, moreover, Kim and Lee (2001) reported that water balance values of rose cut flowers held in water changed to a negative value faster than those held in preservative solutions containing sucrose, 8-HQS in cut flowers of roses. Ali and Hassan (2014) found that treating bird of paradise flowers with 8-HQS and $\mathrm{GA}_{3}$ increased longevity, vase life and postharvest quality. 
Table (4): Effect of different vase solutions on water balance (g/ flower/ day) of carnation, Dianthus caryophyllus.cv Felice cut flowers in the first season (2008).

\begin{tabular}{|c|c|c|c|c|c|c|c|}
\hline \multirow{2}{*}{\multicolumn{2}{|c|}{ Vase solutions }} & \multicolumn{6}{|c|}{ Days after treatments } \\
\hline & & 2 & 4 & 6 & 8 & 10 & 12 \\
\hline 1. & Distilled water & 0.95 & 0.77 & $\mathbf{0 . 6 5}$ & -2.02 & -1.49 & -1.26 \\
\hline 2. & 300 ppm 8-HQS & 1.55 & 0.29 & $\mathbf{0 . 3 9}$ & 0.68 & -0.83 & -0.84 \\
\hline 3. & $300 \mathrm{ppm} 8-\mathrm{HQS}+40 \mathrm{~g} / \mathrm{l}$ sucrose & 1.13 & 0.85 & 0.97 & $\mathbf{0 . 5 9}$ & 0.71 & -0.32 \\
\hline 4. & 150 ppm 8-HQS & 0.88 & 0.76 & 0.99 & -0.76 & -2.62 & -1.9 \\
\hline 5. & $150 \mathrm{ppm} 8-\mathrm{HQS}+20 \mathrm{~g} / \mathrm{l}$ sucrose & $\mathbf{0 . 7 3}$ & $\mathbf{0 . 4 5}$ & 1.56 & 1.37 & $\mathbf{0}$ & -2.05 \\
\hline 6. & $0.4 \mathrm{mM}$ STS for $6 \mathrm{~h}$. & $\mathbf{0 . 4 2}$ & 1.16 & 0.72 & 0.24 & $\mathbf{0}$ & -1.59 \\
\hline 7. & $0.4 \mathrm{mM}$ STS for $6 \mathrm{~h} .+50 \mathrm{~g} / \mathrm{l}$ sucrose & 0.73 & 0.66 & 2.99 & 1.31 & 1.56 & -0.68 \\
\hline 8. & 150 ppm Citric acid & 1.34 & 0.78 & $\mathbf{0 . 8 8}$ & 0.53 & -0.61 & -0.35 \\
\hline 9. & $150 \mathrm{ppm}$ Citric acid + $20 \mathrm{~g} / \mathrm{l}$ sucrose & 0.96 & 1.63 & 1.63 & 0.69 & 0.41 & -0.37 \\
\hline 10. & 200 ppmAluminum sulphate & 0.65 & 0.94 & 0.72 & -0.28 & -2.71 & -1.04 \\
\hline 11. & $\begin{array}{l}50 \mathrm{ppm} \text { GA3 for } 24 \mathrm{~h} \text {. then placed in } 200 \\
\text { ppm Aluminum sulphate }\end{array}$ & 0.66 & 0.42 & 0.86 & 2.93 & 0.79 & -0.4 \\
\hline 12. & $\begin{array}{l}50 \mathrm{ppm} \text { BA for } 24 \mathrm{~h} \text {. then placed in } 200 \\
\text { ppm Aluminum sulphate }\end{array}$ & 0.76 & 0.92 & 0.81 & -0.61 & -2.92 & -2.55 \\
\hline 13. & $\begin{array}{l}50 \text { ppm GA3 for } 24 \mathrm{~h} \text {. then placed in } 200 \\
\text { ppm 8-HQS }\end{array}$ & 0.47 & 0.41 & 0.6 & -0.27 & -1.11 & -1.22 \\
\hline 14. & $\begin{array}{l}50 \text { ppm BA for } 24 \mathrm{~h} \text {. then placed in } 200 \\
\text { ppm 8-HQS }\end{array}$ & 0.68 & 1.05 & 0.94 & -0.33 & -0.02 & -8.71 \\
\hline
\end{tabular}

Table (5): Effect of different vase solutions on water balance (g/flower /day) of carnation, Dianthus caryophyllus.cv Felice cut flowers in the second season (2009).

\begin{tabular}{|c|c|c|c|c|c|c|c|}
\hline \multirow{2}{*}{\multicolumn{2}{|c|}{ Vase solutions }} & \multicolumn{6}{|c|}{ Days after treatments } \\
\hline & & 2 & 4 & 6 & 8 & 10 & 12 \\
\hline 1. & Distilled water & -0.54 & 0.41 & 1.95 & -0.99 & -1.59 & -1.7 \\
\hline 2. & 300 ppm 8-HQS & 2.71 & 0.07 & 0.51 & 0.45 & -0.68 & -0.57 \\
\hline 3. & $300 \mathrm{ppm}$ 8-HQS + $40 \mathrm{~g} / \mathrm{l}$ sucrose & 5.21 & -2.57 & 1.06 & 1.71 & $\mathbf{0}$ & -1.7 \\
\hline 4. & 150 ppm 8-HQS & 1.28 & 0.11 & 0.11 & -3.08 & 12.09 & -1.71 \\
\hline 5. & $150 \mathrm{ppm} 8-\mathrm{HQS}+20 \mathrm{~g} / \mathrm{l}$ sucrose & -0.05 & -3.51 & $\mathbf{0 . 0 3}$ & 1.77 & -2.86 & -2.35 \\
\hline 6. & $0.4 \mathrm{mM}$ STS for $6 \mathrm{~h}$. & -3.96 & 6.36 & 0.05 & 0.23 & 1.05 & -3.24 \\
\hline 7. & $0.4 \mathrm{mM}$ STS for $6 \mathrm{~h} .+50 \mathrm{~g} / \mathrm{l}$ sucrose & -0.88 & 3.72 & 2.89 & 3.35 & 0.1 & 3.98 \\
\hline 8. & 150 ppmCitric acid & 3.09 & -1.86 & 0.5 & 5.07 & -4.97 & 2.99 \\
\hline 9. & $150 \mathrm{ppm}$ Citric acid $+20 \mathrm{~g} / \mathrm{l}$ sucrose & 2.01 & 0.16 & 1.81 & -0.19 & -0.93 & -2.59 \\
\hline 10. & $200 \mathrm{ppm}$ Aluminum sulphate & 1.6 & -0.57 & 1.1 & $\mathbf{0}$ & -2.76 & -3.75 \\
\hline 11. & $\begin{array}{l}50 \mathrm{ppm} \text { GA3 for } 24 \mathrm{~h} \text {. then placed in } \\
200 \mathrm{ppm} \text { Aluminum sulphate }\end{array}$ & -0.41 & -0.46 & 2.55 & 0.1 & 5.82 & 8.61 \\
\hline 12. & $\begin{array}{l}50 \mathrm{ppm} \text { BA for } 24 \mathrm{~h} \text {. then placed in } 200 \\
\text { ppm Aluminum sulphate }\end{array}$ & 0.57 & 1.1 & 0.09 & $\mathbf{1 . 0 3}$ & -2.38 & -13.1 \\
\hline 13. & $\begin{array}{l}50 \mathrm{ppm} \text { GA3 for } 24 \mathrm{~h} \text {. then placed in } \\
200 \mathrm{ppm} \mathrm{8-HQS}\end{array}$ & 0.23 & -0.22 & -0.55 & 1.03 & -1.73 & 0.65 \\
\hline 14. & $\begin{array}{l}50 \text { ppm BA for } 24 \mathrm{~h} \text {. then placed in } 200 \\
\text { ppm 8-HQS }\end{array}$ & 0.69 & -0.09 & 0.31 & 0.69 & -3.49 & -4.35 \\
\hline
\end{tabular}

\section{REFERENCES}

Ali E. and Hassan F. (2014). Postharvest quality of Sterlitzia reginae, Ait. cut flowers in relation to 8-hydroxyquinoline sulphate and gibberellic acid treatments. Sci., Agric., 2 (2):77-82.

Asfarani M., Davaryneiad G. and Tehranifar A. (2008). Effects of pre-harvest calcium fertilization on vase life of rose cut flowers cv. Alexander. Acta Hort., 804: 217-221.
Asrar A. W. A. (2012). Effects of some preservative solutions on vase life and keeping quality of snapdragon (Antirrhinum majus L.) cut flowers. J. Saudi Soc. Agri. Sci., 11:29-35.

Bhaskar V. V., Rao P. V. and Reddy Y. N. (2003). Effect of certain chemicals on vase life of cut roses. J. of Ornamental Hort., $b(2): 113-118$.

Chen D. S., Li N. H., Wang J. M., Ding Y. X. 
and Wang X.J. (2004). Effect of calcium chloride on preservation of cut flowers of Gerbera hybrida.Acta Botanic Yunnanica, 26 (3): 345-348.

Elgimabi M. N. and Sliai A. M. (2013). Effect of preservative solutions on vase life and postharvest qualities of rose cut flowers (Rosa damascena cv. Trigintipetala). American-Eurasin J. Agric. \& Environ. Sci., 13(1): 72-80.

El-Hindi K. M. (2012). Effects of postharvest pretreatments and preservative solutions on vase life longevity and flower quality of sweet pea (Lathyrus odoratus L.). Photosynthica, 50 (3): 371-379.

El-Zohaiy N. A. (1999). Effect of post harvest treatments on some cut flowers. M. Sc Thesis, Fac. Agric., Zagazig Univ., Egypt.

Gue W. M., Zheng L., Zhang Z. H. and Zeng W.Q. (2004) Photohormones regulate senescence of cut chrysanthemum. Acta Hort., 6(24): 349-353 .

Gul F. and Taher I. (2013). Efficacy of STS pulsing and floral preservative solutions on senescence and postharvest performance of Narcissus pseudonarcissus cv. Emperor. Trends in Hort. Res., 3: 14- 26.

Halevy A.H. and Mayak S. (1981). Senescence and post harvest physiology of cut flowers. Hort. Rev. Part, II -3:59-143.

He S.G., Joyce D.C., Irving D.E., Faragher J.D., (2006).Stem-end blockage in cut Grevillea 'Crimson Yul-lo' inflorescences. Postharvest Biol. Tech., 41, 78-84.

Ichimura (2002). Variation with the cultivar in the vase life of cut rose flowers. Bulletin of the National Institute of Floricultural Science, 2: 9-20.

Kazimi M., Zamani S. and Aran M. (2011). Effect of some treatment chemicals on keeping quality and vase life of cut flowers. Am. Plant Physiol., 6: 99-105.

Kim Y. A. and Lee J. S. (2001). Vase life and water balance of cut rose cultivars as affected by preservative solutions containing sucrose, 8-hydroxyquinoline sulfate, ethionine and aluminum sulfate. J. of the Korean Soc. Hort. Sci.,42(3):325-330.

Kim Y. and Lee J. S.(2002). Changes in bent neck, water balance and vase-life of cut rose cultivars affected by preservative solution. J. Korean Soc. Hort. Sci., 43(2):201-207.

Knee M. (2000). Selection of biocides for use in floral preservatives. Postharvest Biol. and
Tech., 18: 227-234.

Mayak S., Halevy A. H., Sagie S., Bar-Yoseph A. and Bravdo B. (1974). The water balance of cut rose flowers. Physiol. Plant., 31: 1522.

Mohammad M. J., Mohsen K., Ahmed K. and Nader H. (2012). Evaluation of aluminium sulphate as vase solution biocide on postharvest microbial and physiological properties of 'Cherry Brandy' rose. Ann. Biolo. Res., 3(2): 1132-1144.

Patil S. R. and Reddy B. S. (2001). Effect of citric acid and sucrose of post harvest water relations, fresh weight and vase life of golden rod (Solidago canadensis L.). Karnataka J. Agric. Sci., 14 (2): 427-430.

Patil S. R., Reddy B. S., Kulharni B. S., Kalasareddi P. T. and Shivaprasad M. (2003). Effect of metal salts, citric acid and 8 -HQS and their combinations on post harvest physiology of golden rod (Solidago canadensis L.) Haryana J. of Hort. Sci., 30 (1/2): 60-61.

Patil S. R. and Reddy B. S. (2005). Effect of citric acid and sucrose on post harvest water relations, fresh weight and vase life of golden rod (Solidago canadensis L.). Mysore J. of Agric. Sci., 39 (1):99-103

Pizano M. (2009). Research shows the way for postharvest treatment roses. Flower Tech., 12 (6): 1-13.

Samaneh B., Ebrahimn H. and Pejman M. (2013). Effect of ascorbic acid, 8-hydroxyqinoline sulphate and sucrose on longevity and anthocyanin content of cut gerbera flowers.Curr. Agric.Res.,1(1):29-33.

Skutnik E., Rabiza-Swider J. and Lukaszewska A. (2006). Evaluation of several chemical for prolonging vase life in cut asparagus greens. J. Fruit and Ornamental Plant Res., 14: 233-240.

Steinitz B. (1982). Role of sucrose in stabilization of cut gerbera flowers stalks. Garten bouwssenchaft, 47 (2): 77-81.

Taha L. S. and Soad M. M. I. (2010). Effect of certain chemical preservative solutions on quality and post harvest shelf life of bird of paradise cut spikes. Egypt. J. Appl. Sci., 25 (1):13-24.

Zamani S., Kazemi M. and Aran M. (2011). Postharvest life of cut rose flowers as affected by salicylic acid and glutamin. World Appl. Sci. J., 12 (9):1621-1624. 
تأثير بعض محاليل الحفظ الكيميائيه على فترة بقاء

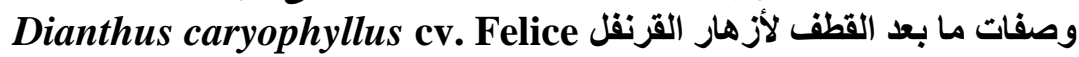

$$
\begin{aligned}
& \text { منى أحمد درويش - فاطمه النبويه محمد عبده القويسني* - إيناس علي يوسف الثريف* } \\
& \text { قسم الزينه ـ كلبة الزراعه - جامعة القاهرة - الجيزة - مصر. }
\end{aligned}
$$

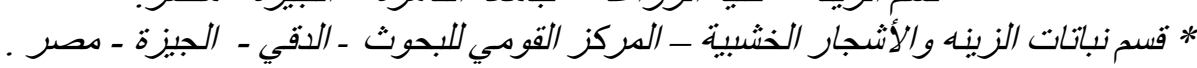

\section{ملخص}

اجريت هذه التجربه في معمل نباتات الزينه و الأشجار الخشبية بالمركز القومي للبحوث بالدقي ـ الجيزة - جمهورية

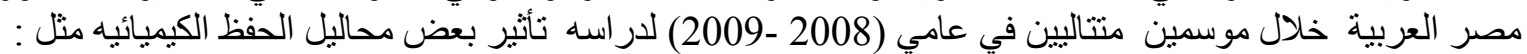
- 8-هيدروكسي كينولين سلفات (BAS)

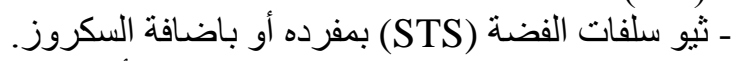

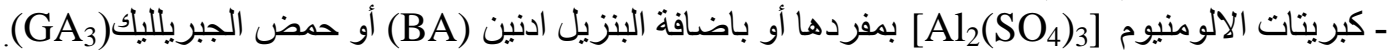

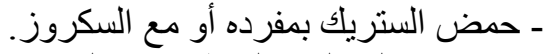
- مالاضافة الى الماء المقطر كمعاملة مقارنها.

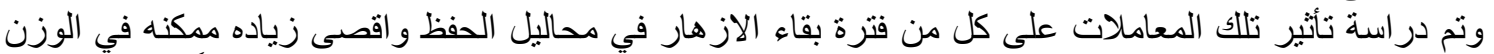

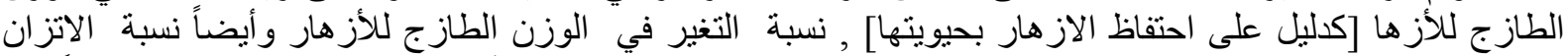

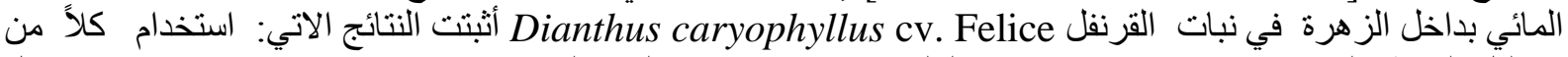

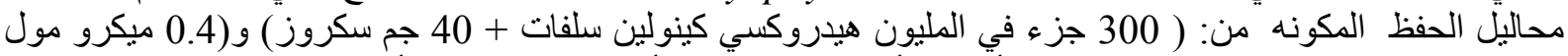

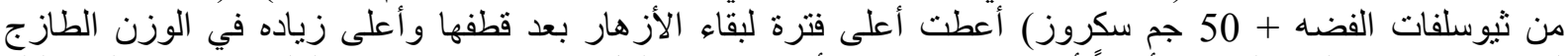

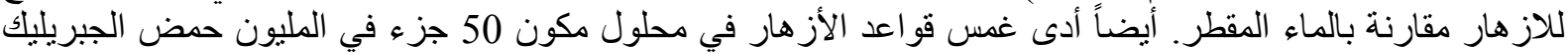

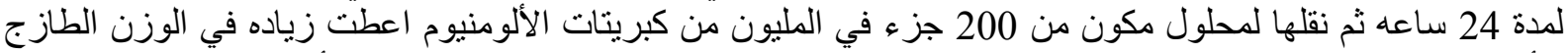

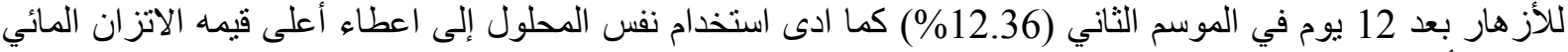

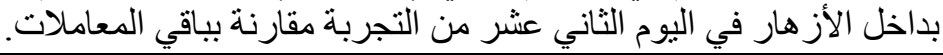

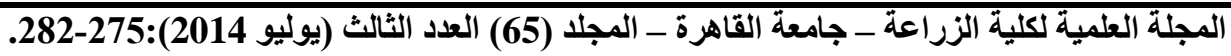

